\title{
Citrullination: the loss of tolerance and development of autoimmunity in rheumatoid arthritis
}

\author{
Citrullinazione: perdita della tolleranza e comparsa di autoimmunità \\ nell'artrite reumatoide
}

\author{
S. Alivernini, A.L. Fedele, I. Cuoghi, B. Tolusso, G. Ferraccioli \\ Divisione di Reumatologia, Università Cattolica del Sacro Cuore, Roma, Italia
}

\begin{abstract}
RIASSUNTO
L'artrite reumatoide $(A R)$ è una malattia caratterizzata da infiammazione cronica, da progressiva formazione di panno sinoviale e distruzione ossea. Le proteine, nel genoma sono codificate da un limitato numero di geni. Modifiche post-traduzionali, come la citrullinazione nei residui di arginina, possono creare diversità strutturali e funzionali. Molte proteine autologhe sono considerate possibili autoantigeni capaci di indurre il processo autoimmune. $\grave{E}$ stato dimostrato che la presenza di anticorpi anticitrullina sia antecedente la comparsa di sintomi di artrite. $\grave{E}$ ipotizzabile che la flogosi sinoviale e la reazione di sintesi del nitrossido, in particolare nel contesto di una genetica predisponente, porti alla risposta autoimmune, nei confronti di antigeni post-traduzionalmente strutturalmente modificati.
\end{abstract}

Reumatismo, 2008; 60(2):85-94

\section{INTRODUCTION}

R heumatoid arthritis (RA) is a chronic inflammatory disease characterized by synovial inflammation and pannus formation, which can lead to severe destruction of cartilage and bone. Several self proteins have been suggested to be disease-driving autoantigens. Moreover the presence of autoantibodies to citrullinated proteins in sera of patients with RA enhances the strength of this hypothesis.

Proteins are encoded by a limited number of genes in our genome. Post-translational modifications such as phosphorylation, glycosylation and citrullination can increase the morphological and the functional diversity of the proteome. Post-transla-

Indirizzo per la corrispondenza:

Prof. Gianfranco Ferraccioli

Cattedra e Clinica di Reumatologia,

Università Cattolica del Sacro Cuore

Via Moscati 31

00168 Roma

E-mail: gf.ferraccioli@rm.unicatt.it tional modifications (PTM) are very common processes that modify specific parts of a protein after its synthesis. To date all known proteins undergo some form of post-translational modification, and every amino acid can be altered by these processes. The modified proteins obtain rare amino acids with critical influence on the structure and function of the original molecule. One of these peptide-bound residues is arginine that can undergo this modification and replaced by citrulline that remains part of the protein as peptidyl citrulline (1). Citrulline is not a natural amino acid in proteins structure and may induce immune response.

\section{THE CITRULLINATION REACTION}

After the conversion of arginine (Arg) to citrulline (Cit), there are changes of the charge of the amino acid. Arginine is a strongly basic residue due to the presence of a guanidino group. The resulting citrulline loses the strong basic character because of its neutral nature (2). 
The conversion process is an enzymatic reaction catalyzed by a family of calcium-binding enzymes called peptidylarginine deiminases (PAD).

During the reaction there is a 1 Dalton mass reduction for each Arginine modified and the basic charge (s) lost influences the overall charge, charge distribution and the isoelectric point of the resulting protein. Even the interactions of the protein with others might be altered (3).

As said before, the deimination process is catalysed by PAD whose five isoenzymes have been identified (4).

These isoenzymes are distributed in many mammalian tissues: PAD1 is mainly expressed in the epidermis and in the female reproductive system; PAD3 in the hair follicles and PAD4, the human homologue of the mouse one, previously named PAD5, in neutrophils and eosinophils. PAD6 has been found in ovaries, in embryos at the early stage of development and in eggs and PAD2 has an ubiquitous distribution (for example skeletal muscles, spleen, brain, secretory glands) (5).

The mechanism of deimination involves the active site of the enzyme with Cys residue that links the guanidino group of the arginine and establishes a tetrahedral transition state while ammonia residue is released. The intermediate is then cleaved after the attack of a water molecule. This last step of the process regenerates the Cys residue and leads to the formation of a ketogroup and a new primary amine (6).

The catalytic process could change the primary, secondary and tertiary structures of proteins. Several in vitro analysis showed that a high degree of citrullination could denature proteins (3) and experiments with filaggrin revealed that change of $5 \%$ of the arginine residues modifies the tertiary structure, and modification of more than $10 \%$ of the arginines leads to a complete denaturation of the protein. So, In vivo, under physiological conditions, it seems possible to assume that the modification alters the protein structure and results in a less organised and more open configuration (3). Consequently this process may influence the interaction of the new molecule with other proteins. Any arginine residue could be deiminated and represent a physiological substrates of PAD enzymes. Several studies have shown various proteins citrullinated in vitro although with different kinetic parameters $(7,8)$. Data reveals some preferences of peptidylarginine deiminases on the primary and secondary structure of the substrate. For example the beta-turn secondary configuration represents the most susceptible region for deimination (3).

Only few proteins in healthy conditions contain citrulline. Some of these are nuclear histones, which have other different post-traslational modifications such as methylation of arginine residues in the aminoacid chain. It seems that citrullination and methylation of arginine residues are competing processes. Pruijn and colleagues, evaluating PAD enzymes from several mouse tissues, showed that they are able only to convert non-methylated arginine into citrulline (9).

Calcium is the key regulator of PAD enzymes. In 2004, Sato and colleagues analysed the structural basis for Calcium-induced activation of human PAD4. They presented the crystal structure of Cafree wild type PAD4, which have five Calcium binding sites in its $3 \mathrm{D}$ conformation. The ion is able to induce conformational changes that generate the opening of the active site in the C-terminal domain. The new conformation is essential for the catalysis (10).

In vitro citrullination is only detectable in the presence of high calcium concentration (11) but in healthy conditions, its concentration range is $10^{-8}-10^{-6} \mathrm{M}$, so PADs are inactive (12). This suggests that the citrullination process happens only under 'extreme' conditions, such as during apoptosis or terminal differentiation of the epidermis. PADs are enzymes primarily involved in apoptotic and differentiation events in physiological conditions and recently they have also been involved in other cellular processes, such as gene regulation $(13,14)$.

\section{AUTOANTIBODIES AGAINST CITRULLINATED PROTEINS}

The history of anti-citrullinated protein antibodies starts in 1964, when Nienhuis and Mandema, performing IIF with RA sera on human buccal mucosa cells, noticed reactivity with an unknown protein component that they called the perinuclear factor $(15,16)$.

Many years later, Young and colleagues (17), through IIF on rat, described the specific staining in the stratum corneum of the esophageal epithelium. Thinking that the target antigen was keratin, these antibodies were called AKA (anti-keratin antibodies). Later it was found that both the APF and the AKA reacted with filaggrin, a citrulline containing protein associated with keratin 
filaments in the citoskeletal structure. These antibodies were named anti-filaggrin antibodies (AFA) (18).

The anti-CCP antibodies are produced locally in the inflamed synovium of RA patients $(19,20)$, suggesting that citrullinated proteins are located in the inflamed synovium. The absence of filaggrin expression in the (inflamed) synovium suggested that other citrullinated proteins should exist in the joint. To investigate this, a library of citrullinated peptides was screened with a pool of RA sera and this resulted in the identification of a number of highly reactive peptides that are currently used in the second generation CCP test (CCP2). This CCP2 test has a sensitivity of about $82 \%$ for RA with $98-99 \%$ of specificity (21). In our cohort of 177 patients with long-standing RA (mean DAS44 value $=2.88 \pm 1.30)$ we found a prevalence of $67.7 \%$ for anti-citrullinated proteins antibodies, compared to a prevalence of $46.3 \%$ for $\operatorname{IgM}$ rheumatoid factor and $37.8 \%$ for $\operatorname{IgA}$ rheumatoid factor (Tab.I).

\section{ANTI-CCP ANTIBODIES ARE PRESENT EARLY IN RA}

Two different studies, using stored samples of sera of patients with RA who were blood donors, showed the presence of anti-CCP antibodies prior to the appearance of the first clinical symptoms of arthritis $(22,23)$.

These studies demonstrated that the positivity of anti-citrullinated peptides autoantibodies and rheumatoid factor autoantibodies is an early stage of the disease development. Data from longitudinal studies underline the predictive power of anti-CCP2 tests for RA development (24-26).

Van Gaalen and colleagues, studying patients attending an early arthritis clinic who were at first classified as undifferentiated arthritis (UA), tried to predict which of these patients would progress to RA in the next years. One year later, $75 \%$ of UA patients who were anti CCP positive developed RA. From the UA group, anti CCP negative at baseline, only $25 \%$ of patients was classified as RA after three years (24). Even Vittecq and colleagues reached similar data. Of 314 UA patients, $90 \%$ of the anti CCP ones were classified as RA at one-year follow up (25). This early aspect may be useful for the clinician in the early diagnosis and in the selection of patients to treat with aggressive therapeutic protocols very early on. In our cohort of 110 early rheumatoid arthritis (ERA) patients the prevalence of anti-CCP positivity is $70.0 \%$ compared to the prevalence of $60.9 \%$ for IgM Rheumatoid Factor and of $43.6 \%$ for IgA rheumatoid factor. In long standing RA (LSRA) we observed a slightly lower prevalence of IgM-RF likely due to the underlying therapy with aggressive combination protocols (Tab. I).

\section{INTRA-ARTICULAR CITRULLINATION}

The first evaluation to address this hypothesis was the clear demonstration of citrullinated proteins in the RA synovium. In synovial tissue specimens the first evidence of the presence of citrullinated peptides was provided by performing immunoblotting analysis $(27,28)$.

Then Serre and colleagues showed the abundant presence of citrullinated alpha and beta fibrin chains at the immunostaining procedure, even if its presence is not specific of RA, since it could be detected even in spondylarthropaties and inflammed osteoarthritis synovium (27). During the years, multiple possible deiminated synoval proteins were found such as: fibronectin, associated with citrullinated fibrin because of their parallel staining $(29,30)$; $\alpha$-enolase, even if Western blotting did not confirm its citrullination in vivo (31);

Table I - Autoimmune profile in patients with early and long standing rheumatoid arthritis. Personal cohort with a long term follow-up.

\begin{tabular}{|lcc|}
\hline & $\begin{array}{c}\text { Long standing RA patients } \\
n=177\end{array}$ & $\begin{array}{c}\text { Early RA patients } \\
n=110\end{array}$ \\
\hline Age, years (mean \pm SD) & $57.1 \pm 13.6$ & $54.9 \pm 13.8$ \\
Disease duration, years (mean \pm SD) & $13.7 \pm 10$ & $0.51 \pm 0.73$ \\
Anti CCP positive, $\mathrm{n}(\%)$ & $120(67.7)$ & $77(70.0)$ \\
RF IgM positive, $\mathrm{n}(\%)$ & $82(46.3)$ & $67(60.9)$ \\
RF IgA positive, $\mathrm{n}(\%)$ & $67(37.8)$ & $48(43.6)$ \\
DAS44 value, (mean $\pm \mathrm{SD})$ & $2.9 \pm 1.3$ & $4.2 \pm 1.1$ \\
\hline
\end{tabular}


Sa antigen,(at first found in human placenta, spleen and RA synovium) was later seen to correspond to vimentin $(32,33)$, Epstein-Barr nuclear antigen 1 (EBNA-1) and nuclear proteins such as histones $(34,35)$.

Different studies showed that PAD4 is expressed in the synovial tissue. Chang and colleagues found that PAD4 is widely expressed in T cells, B cells, macrophages, neutrophils, fibroblast-like cells and endothelial cells in the lining and in the sublining areas of the RA synovium. They underlined that this expression has intra and extracellular distribution, generally associated with fibrin deposits.

This co-localization suggests that PAD4 is responsible for fibrin citrullination that may be a potential antigen of RA autoimmunity (36).

The anti-citrulline autoantibodies are thought to be produced by local plasma cells, since significant amounts of anti-citrullinated peptides antibodies have been measured in synovial cells cultures supernatants of tissue from anti-filaggrin antibody-positive RA patients (37).

Moreover anti CCP producing B cells were found in the synovial fluid of RA patients. Isolating $B$ cells from synovial fluid or bone marrow from anti CCP-positive patients, it was found that they are able to produce $\operatorname{IgM}$ anti-CCP antibodies without stimulation, whereas $\mathrm{B}$ cells from peripheral blood required stimulation (38). So the clear presence of such active B cells directly in the synovial cavity underlines the antigen-driven nature of the inflammatory process. Alternatively, it is likely that the response to citrullinated proteins, rather than their presence, is specific for RA (39). Recently, citrullinated proteins were found even in synovial exosomes (40). Exosomes are saucer shaped vesicles with a diameter of 30-10 nm, that are released from cells after the fusion of multiple endosomes to the cell surface. These particles with their modified content could stimulate T cellproliferation and play an important role in $\mathrm{B}$ cell activation even directly stimulating the BCR through the presentation of autoantigenic peptides on their surface (41).

Distler and colleagues showed that during specific cells conditions, apoptosis or activation, there is an increased release of microparticles from $T$ cells and monocytes. These phenomena are very frequent and abundant in inflammatory disease such as Rheumatoid Arthritis and may represent a novel stimulatory way for the release of cytokines, chemokines and inflammatory mediators (42).

\section{EXTRA-ARTICULAR SITES OF CITRULLINATION}

This enzymatic process normally occurs in specific backgrounds as epidermal differentiation, growth of hair follicles and maturation and differentiation of myelin during the development of the central nervous system (43). Makrygiannakis and colleagues in 2006, evaluated the presence of citrullinated proteins in synovial biopsies specimens from patients with RA, healthy controls, myositis-affected muscles, inflamed tonsil tissues and intestinal tissue from patients with inflammatory bowel disease. The presence of citrullinated proteins in all the specimens characterized by chronic inflammation suggested to the authors that this process is inflammation rather than disease dependent (44).

The citrullination phenomenon is not only present in synovial tissue of patients with RA but can also occur in extra-articular targets involved by the disease. Moreover it is not clear if it could contribute to the local disease process by an anti citrullinated peptides autoantibodies mediated way. Bongartz and colleagues detected the presence of citrulline in lung specimens of patients with RA associated interstitial pneumonia (IP) and patients with idiopathic IP compared with healthy controls (45).

They found that, although anti citrulline antibodies has high specificity for RA, citrullination was not restricted to patients with RA associated IP but can also be found in idiopathic IP (45). The citrulline staining was found to be principally with an intracellular location, inside mononuclear cells. this aspect seems to be of great relevance in the light of recent insight in the role of positive and negative selection of autoreactive B-cells depending on the cellular antigen distribution: intracellular antigens may lead to positive B-ell selection and enhances autoantibodies production (46). The next step will be the biochemical characterization of deiminated peptides from fresh RA lung tissue and the comparison with the citrullinated ones in the synovium (45).

\section{GENETIC LINKS WITH CITRULLINATION IN RA}

\section{PAD polymorphisms}

Suzuki an colleagues described the existence of several single nucleotide polymorphisms (SNPs) 
in the PAD gene (located on chromosome 1p36). 8 of the 17 SNPs in PAD4 gene were clearly associated with RA. These different SNPs are characterized by a linkage disequilibrium association and this is the reason of their segregation together in distinct haplotypes. Four of the 17 SNPs of PAD4 involves the exons of the same gene. Three of them leads to an aminoacid substitution but only one of the three aminoacid substitution is associated with a change in the electrostatic charge of the residue (39).

Different SNPs in the gene encoding for PAD4, that have been assigned as a susceptibility haplotype to the development of RA, are thought to make PAD4 mRNA more resistant to cellular degradation even if few is known about the relationship between the aminoacid replacement and the final protein function. Suzuki and colleagues evaluated the mRNA stability in vitro and found that stability of susceptible transcripts is higher (approximately threefold) than that of nonsusceptible transcripts (39).

They did not evaluate the possible differences in PAD4 mRNA and protein levels comparing patients with susceptible haplotype versus those with nonsusceptible one. However they suggested that the over-resistance and stability of PAD4 mRNA could lead to a higher citrullination level and the appearance of autoantigens. This hypotesis is supported by the finding that patients carrying the susceptible haplotype in homozygosis have significantly higher anti citrulline antibodies titer $(87 \%$ versus $67 \%, \mathrm{p}<0,05)$ compared with heterozygosis or nonsusceptible haplotype homozygosis (47).

\section{HLA genes: the shared epitope}

Since thirty years ago, several studies about the genes-linkage have shown a strong correlation between RA and some HLA-DR alleles, in particular HLADRB $1 * 0401$ and HLA-DRB1*0404 (48, 49).

The so called "shared epitope" has been shown to be contained on the third hypervariable (HV3) region of DRB1. This HV3 motif in RA-associated alleles consists of ${ }^{70} \mathrm{QKRAA}^{74}$ or ${ }^{70} \mathrm{QRRAA}^{74}$ in DRB $1 * 0401$ and DRB $1 * 0404$, respectively (50). These five-AA sequence is crucial to determine the $\mathrm{p} 4$ peptide-binding pocket of the DRB1 molecule. Thanks to the positive charge at position 71 this pocket has a very high affinity for negatively charged or uncharged polar molecules (51). Therefore, the SE hypothesis became one of the most well-known hypothesis in the field of HLA and disease associations.

During the citrullination process there is the conversion of the positively charged iminogroup of arginine to the uncharged carbonyl group of citrulline. This may increase the peptide affinity for SE-positive DRB1 molecules (52).

Huizinga and colleagues demonstrated that the SE epitope was associated with anti citrullinated peptides autoantibodies(ACPA)-positive RA patients and not with ACPA-negative RA (53). Analysing if the RF and ACPA associations with SE were independent they found that the association between SE and RF was secondary to the association between SE and ACPA. Analysing the influence of the SE and ACPA on the evolution of recent onset undifferentiated arthritis (UA) to RA, no contribution of the SE was observed on the progression to RA (53).

In order to evaluate if SE-positive HLA DRB1 alleles was associated with the onset of ACPA positive RA or only with ACPA positivity, De Vries and colleagues analysed SE and ACPA influence in the progression of recent undifferentiated arthritis (UA) into RA in a cohort of patients. No contribution on the progression to RA from UA was observed for SE and its presence was associated only with a higher titer of these autoantibodies. According to the authors, the SE alleles do not contribute to the progression of UA into RA but clearly in the development of anti-citrullinated peptides autoantibodies (54).

\section{CITRULLINATION: UNIQUE ORIGIN?}

As said before, citrulline formation depends on the conversion of arginine catalysed by PAD enzymes. However citrulline can be formed even as a side product when nitric oxide (NO) is generated from arginine by NO syntetase (NOS).

NOS enzymes can be divided in two separated domains: a C-terminal reductase domain and an $\mathrm{N}$-terminal oxygenase domain (55). There are three isoforms of NOS: endothelial NOS (eNOS) and neuronal NOS (nNOS) that are constitutively expressed, Calcium dependent enzymes, even if eNOS can also be activated in a Calcium independent way; inducible NOS (iNOS) whose activation depends on the presence of cytokines ad inflammatory molecules with a calcium-independent activity (55).

One of the feature of a good-working immune 
system is the production of NO: dendritic cells, NK cells, mast cells and phagocytic cells including monocytes, macrophages, Kupffer cells, neutrophils and other cells involved in immune reactions generate NO (56).

Several factors are involved in the regulation of the expression and the action of NOS. IL-12 and IL-18 are thought to be important in the induction of iNOS expression in macrophages in an IFNgamma dependent manner (57). Many cytokines, as TNF, IL-1, IL-4, TGF-beta are able to induce/suppress guanosine triphosphate cyclohydrolase I, the key enzyme of BH4 synthesis, an essential metabolite for NOS catalysis $(56,58)$.

At first, NO produced in the site of inflammation, by macrophages expressing iNOS was considered a damaging molecule $(59,60)$. Analyses on experimental autoimmune diseases such as arthritis, uveitis or encephalomyelitis showed the NOS ability to function as a negative feedback molecule of the TH1 cell response $(61,62)$. In fact, treating an experimental autoimmune arthritis (EAA) with an arginine analogue able to inhibit all NOS isoforms, there is a improvement of the disease, while using a selective iNOS inhibitor there is no protective effect but even a worsening of arthritis $(63,64)$.

In a recent study, Ling and colleagues investigated the possible link between NO and the shared epitope effect. They found that cells with LADRB 1 alleles presented an increased constitutive NO production. Even murine cells expressing human SE DR molecules after transfection, showed the same increasing, underlining that there is no linkage disequilibrium with another gene (65).

\section{ENVIRONMENTAL FACTORS: SMOKING HABIT}

Cigarette smoking has been shown to have a high association with RA (66-73). At first smoking was

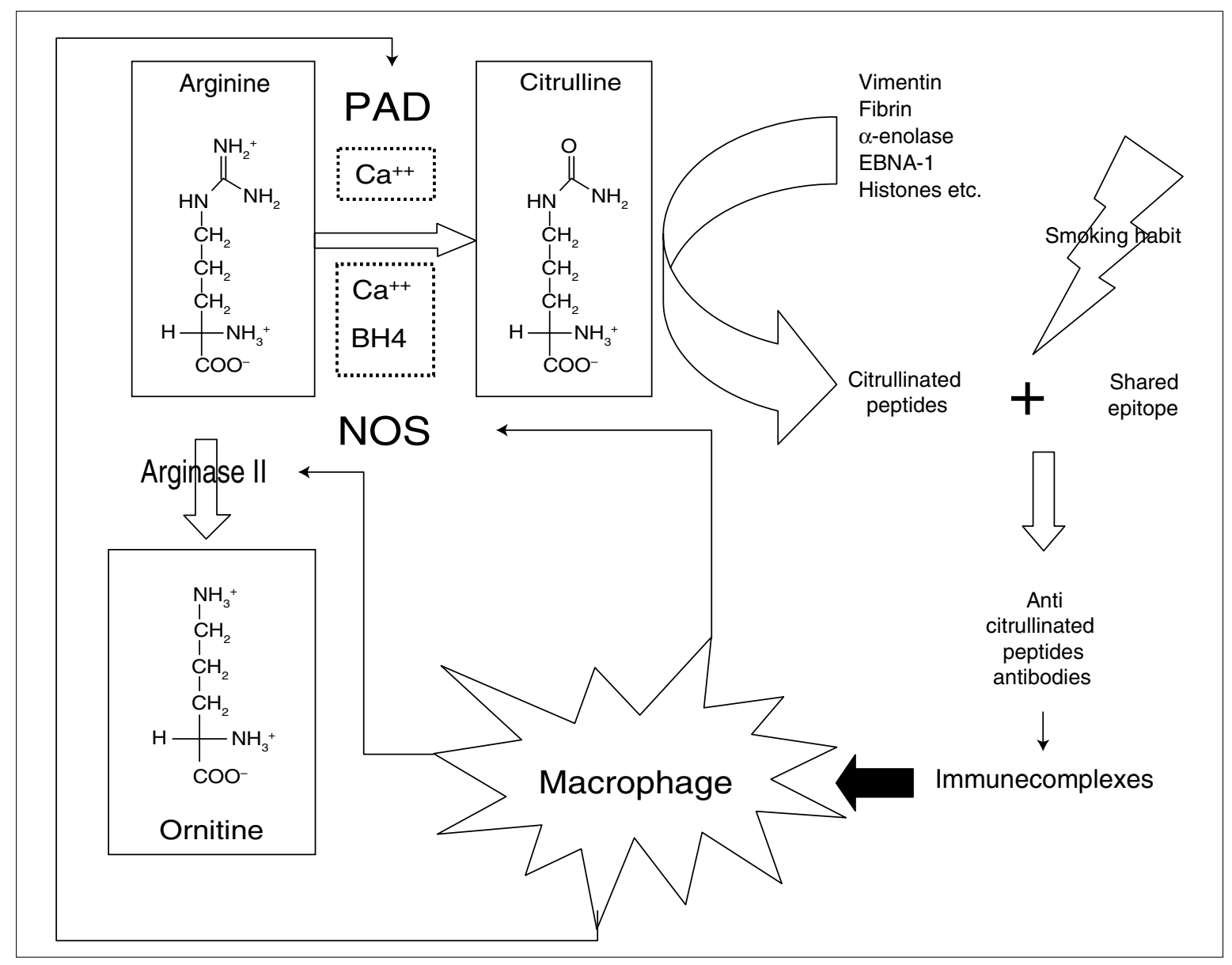

Figure 1 - Loss of tolerance to citrullinated proteins in RA: possible biological mechanisms. 
associated with Rheumatoid factor-positive RA and considered to interact with the HLA-DRB1 alleles $(74,75)$. More recently, Klareskog and colleagues demonstrated that smoking habit and HLA-DRB1 SE were risk factors only for anti-citrulline positive, but not anti-citrulline negative RA and that HLADRB1 SE was linked to presence of anti-citrulline immunity rather than to presence of rheumatoid factors (76). The same authors demonstrated even an increased level of citrullination in bronchoalveolar lavage fluid cells from smokers even if another group did not find a significant difference in citrulline staining lung specimens from patients with RA associated IP comparing with idiopathic IP (45). In order to confirm the interaction between cigarette smoking and shared epitope, Lee and colleagues recently performed an analysis of three North American RA cohorts. They found that the shared epitope correlated with the anti citrullinated peptides autoantibodies in all three cohorts but only in two a significant correlation between smoking and ACPA was found. After a multiple logistic regression analysis, carrying the shared epitope is still the most significant risk factor for ACPA development but a possible interaction between shared epitope and smoking for ACPA positivity was not confirmed (77). Recent data suggest that environmental factors contribute to anti-CCP autoantibodies in patients carrying the shared epitope, but not in those without the genetic setting (78).

\section{BIOLOGICAL INTERPRETATIONS OF GENE, ENVIRONMENT AND IMMUNITY INTERACTION IN RA}

All these biological and clinical data suggest that citrullination in a definite genetic setting allows the emergence of the loss of tolerance to several proteins (Fig. 1). Why the loss of tolerance occurs, because of the citrullination, is not yet fully defined, but the increased affinity for the DRB1 task of the shared epitope might provide the clue to understand the autoreactivity. How to control the loss of tolerance and how to possibly rescue the control of autoreactivity in the earliest phases of the disease remains a matter of further investigations.

\begin{abstract}
SUMMARY
Rheumatoid arthritis (RA) is a chronic inflammatory disease characterized by synovial inflammation and pannus formation leading to destruction of cartilage and bone. Several self proteins have been suggested to be disease-driving autoantigens. Proteins are encoded by a limited number of genes in our genome. Post-translational modifications such as citrullination of the arginine residues, can increase the morphological and the functional diversity of the proteome. The positivity of anti-citrullinated peptides autoantibodies occurs then at an early stage of the disease development. Several factors, among which the synovial tissue inflammatory and the nitric oxide reaction, are involved in the regulation of the citrullination reaction. All of them have to be analysed and considered to understand the loss of tolerance and the development of autoimmunity leading to the disease.
\end{abstract}

Parole chiave - Artrite reumatoide, citrullina, anticorpi anti-peptidi citrullinati, perdita della tolleranza, autoimmunità. Key words - Rheumatoid arthritis, citrulline, anti-citrullinated peptides antibodies, loss of tolerance, autoimmunity.

\section{REFERENCES}

1. Fearon WR. The carbamido diacetyl reaction: A test for citrulline. Biochem J 1939; 33: 902-7.

2. van Venrooij WJ, Pruijn, GJ. Citrullination: A small change for a protein with great consequences for rheumatoid arthritis. Arthritis Res 2000; 2: 249-51.

3. Tarcsa E, Marekov LN, Mei G, Melino G, Lee SC, Steinert PM. Protein unfolding by peptidylarginine deiminase. Substrate specificity and structural relationships of the natural substrates trichohyalin and filaggrin. J Biol Chem 1996; 271: 30709-16.

4. Chavanas S, Mechin MC, Takahara H, Kawada A, Nachat R, Serre G, et al. Comparative analysis of the mouse and human peptidylarginine deiminase gene cluster reveals highly conserved non-coding segments and a new human gene, PADI6. Gene 2004; 330: 19-27.

5. Vossenaar ER, Zendman AJ, van Venrooij WJ, Pruijn GJ. PAD, a growing family of citrullinating enzymes: Genes, features and involvement in disease. Bioessays 2003; 25: 1106-18.

6. Arita K, Hashimoto H, Shimizu T, Nakashima K, Yamada M, Sato M. Structural basis for $\mathrm{Ca}(2+)$-induced activation of human PAD4. Nat Struct Mol Biol 2004; 11: 777-83.

7. Kubilus J, Baden HP. Purification and properties of a brain enzyme which deiminates proteins. Biochim Biophys Acta 1983; 745: 285-91. 
8. Kubilus J, Waitkus RF, Baden HP. Partial purification and specificity of an arginine-converting enzyme from bovine epidermis. Biochim Biophys Acta 1980; 615: 246-51.

9. Raijmakers R, Zendman AJ, Egberts WV, Vossenaar ER, Raats J, Soede-Huijbregts C, et al. Methylation of arginine residues interferes with citrullination by peptidylarginine deiminases in vitro. J Mol Biol 2007; 367 : 1118-29.

10. Suzuki A, Yamada R, Chang X, Tokuhiro S, Sawada T, Suzuki M, et al Functional haplotypes of PADI4, encoding citrullinating enzyme peptidylarginine deiminase 4 , are associated with rheumatoid arthritis. Nat Genet 2003; 34: 395-402.

11. Mechin MC, Enji M., Nachat R, Chavanas S, Charveron, M, Ishida-Yamamoto A, et al. The peptidylarginine deiminases expressed in human epidermis differ in their substrate specificities and subcellular locations. Cell Mol Life Sci 2005; 62: 1984-95.

12. Takahara, H, Okamoto, H, Sugawara, K. Calciumdependent properties of peptidylarginine deiminase from rabbit skeletal muscle. Agric Biol Chem 1986; 50: 2899-904.

13. Senshu T, Akiyama K, Nagata S, Watanabe K, Hikichi $\mathrm{K}$. Peptidylarginine deiminase in rat pituitary: Sex difference, estrous cycle-related changes, and oestrogen dependence. Endocrinology 1989; 124: 2666-70.

14. Takahara H, Kusubata M, Tsuchida M, Kohsaka T, Tagami S,Sugawara Expression of peptidylarginine deiminase in the uterine epithelial cells of mouse is dependent on oestrogen. J Biol Chem 1992; 267: 520-5.

15. Vossenaar ER, van Venrooij WJ. Anti-CCP antibodies, a highly specific marker for (early) rheumatoid arthritis. Clin Appl Immunol Rev 2004; 4: 239-62.

16. Nienhuis RL, Mandema E. A new serum factor in patients with rheumatoid arthritis; the antiperinuclear factor. Ann Rheum Dis 1964; 23: 302-5.

17. Young BJ, Mallya RK, Leslie RD, Clark CJ, Hamblin TJ. Anti-keratin antibodies in rheumatoid arthritis. $\mathrm{Br}$ Med J 1979; 2: 97-9.

18. Sebbag M, Simon M, Vincent C, Masson-Bessie`re C, Girbal E, Durieux JJ, et al. The antiperinuclear factor and the so-called antikeratin antibodies are the same rheumatoid arthritis-specific autoantibodies. J Clin Invest 1995; 95: 2672-9.

19. Masson-Bessie`re C, Sebbag M, Durieux JJ, Nogueira L, Vincent C, Girbal-Neuhauser E, et al. In the rheumatoid pannus, anti-filaggrin autoantibodies are produced by local plasma cells and constitute a higher proportion of IgG than in synovial fluid and serum. Clin Exp Immunol 2000; 119: 544-52.

20. Reparon-Schuijt CC, van Esch WJ, van Kooten C, Schellekens GA, de Jong BAW, van Venrooij WJ, et al. Secretion of anti-citrulline-containing peptide antibody by B lymphocytes in rheumatoid arthritis. Arthritis Rheum 2001; 44: 41-7.

21. van Venrooij WJ, Hazes JM, Visser H. Anticitrullinated protein/peptide antibody and its role in the diagnosis and prognosis of early rheumatoid arthritis. Neth J Med 2002; 60: 383-8.
22. Rantapää-Dahlqvist S, de Jong BA, Berglin E, Hallmans G, Wadell G, Stenlund H, et al. Antibodies against cyclic citrullinated peptide and IgA rheumatoid factor predict the development of rheumatoid arthritis. Arthritis Rheum 2003; 48: 2741-9.

23. Nielen MM, van Schaardenburg D, Reesink HW, van de Stadt RJ, van der Horst-Bruinsma IE, de Koning $\mathrm{MH}$, et al. Specific autoantibodies precede the symptoms of rheumatoid arthritis: a study of serial measurements in blood donors. Arthritis Rheum 2004; 50: 380-6.

24. van Gaalen FA, Linn-Rasker SP, van Venrooij WJ, de Jong BA, Breedveld FC, Verweij CL, et al. Autoantibodies to cyclic citrullinated peptides predict progression to rheumatoid arthritis in patients with undifferentiated arthritis: a prospective cohort study. Arthritis Rheum 2004; 50: 709-15.

25. Vittecoq O, Incaurgarat B, Jouen-Beades F, Legoedec J, Letourneur O, Rolland D, et al. Autoantibodies recognizing citrullinated rat filaggrin in an ELISA using citrullinated and non-citrullinated recombinant proteins as antigens are highly diagnostic for rheumatoid arthritis. Clin Exp Immunol 2004; 135: 173-80.

26. Soderlin MK, Kastbom A, Kautiainen H, Leirisalo-Repo M, Strandberg G, Skogh T. Antibodies against cyclic citrullinated peptide (CCP) and levels of cartilage oligomeric matrix protein (COMP) in very early arthritis: relation to diagnosis and disease activity. Scand J Rheumatol 2004; 33: 185-8.

27. Chapuy Regaud S, Sebbag M, Girbal-Neuhauser E, Nogueira L, Vincent C, Senshu T et al. Fibrin deimination in synovial tissue is not specific for rheumatoid arthritis but commonly occurs during synovitidies. J Immunol 2005; 174: 507-64.

28. Masson-Bessiere C, Sebbag M, Girbal-Neuhauser E, Nogueira L, Vincent C, Senshu T et al. The mayor synovial targets of the rheumatoid arthritis-specific antifilagrin autoantibodies are determinated forms of the alpha and beta chains of fibrin. J Immunol 2001; 166: 417-84.

29. Sanchez-Pernaute O, Largo R, Calvo E, Alvarez-Soria MA, Egido J, Herrero-Beaumont G. A fibrin based model for rheumatoid synovitis. Ann Rheum Dis 2003; 62: $1135-8$.

30. Scott JP, Gerber P, Maryjowski MC, Pachman LM. Evidence for intravascular coagulation in systemic onset, but not polyarticular, juvenile rheumatoid arthritis. Arthritis Rheum 1985; 28: 256-61.

31. Chang X, Yamada R, Suzuki A, Kochi Y, Sawada T, Yamamoto K. Citrullination of fibronectin in rheumatoid arthritis synovial tissue. Rheumatology (Oxford) 2005; 44: 1374-82.

32. Despres N, Boire G, Lopez-Longo FJ, Menard HA. The Sa system: a novel antigen-antibody system specific for rheumatoid arthritis. J Rheumatol 1994; 21: 102733.

33. Vossenaar ER, Despres N, Lapointe E, van der Heijden A, Lora M, Senshu T, et al. Rheumatoid arthritis specific anti-Sa antibodies target citrullinated vimentin. Arthritis Res Ther 2004; 6: R142-50. 
34. Nakashima K, Hagiwara T, Yamada M. Nuclear localization of peptidylarginine deiminase $\mathrm{V}$ and histone deimination in granulocytes. J Biol Chem 2002; 277: 49562-8.

35. Wang Y, Wysocka J, Sayegh J, Lee YH, Perlin JR, Leonelli L, et al. Human PAD4 regulates histone arginine methylation levels via demethylimination. Science 2004; 306: 279-83.

36. Chang X, Yamada R, Suzuki A, Sawada T, Yoshino S., Tokuhiro $S$ et al. Localization of peptidylarginine deiminase 4 (PADI4) and citrullinated protein in synovial tissue of rheumatoid arthritis Rheumatology 2005; 44: 40-50.

37. Cornelis F, Fauré S, Martinez M, Prud'homme JF, Fritz P, Dib C, et al. New susceptibility locus for rheumatoid arthritis suggested by a genome-wide linkage study. Proc Natl Acad Sci USA 1998; 95: 1074650.

38. Shiozawa S, Hayashi S, Tsukamoto Y, Goko H, Kawasaki H, Wada T, et al. Identi.cation of the gene loci that predispose to rheumatoid arthritis. Int Immunol 1998; 10: 1891-5.

39. Suzuki A, Yamada R, Chang X, Tokuhiro S, Sawada T, Suzuki M, et al. Functional haplotypes of PADI4, encoding citrullinating enzyme peptidylarginine deiminase 4, are associated with rheumatoid arthritis. Nat Genet 2003; 34: 395-402.

40. Skriner K, Adolph K, Jungblut PR, Burmester GR. Association of citrullinated proteins with synovial exosoes. Athritis Rheum. 2006; 12: 3809-14.

41. Thery C, Duban L, Segura E, Véron P, Lantz O, Amigorena S. Indirect activation of naive CD4+ T cells by dendritic cell-derived exosomes. Nat Immunol 2002; 3: 1156-62.

42. Distler JH, Jüngel A, Huber LC, Seemayer CA, Reich CF 3rd, Gay RE, et al. The induction of matrix metalloproteinase and cytokines expression in synovial fibroblasts stimulated with immune cells microparticles. Proc Natl Acad Sci USA 2005; 102: 2892-7.

43. Bence Gyorgy, Erzsébet Tòth, Edit Tarcsa, Andràs Falus, Edit I. Buzàs Citrullination: A posttranslational modification in health and disease The International Journal of Biochemistry \& Cell Biology 2006; 38 : 1662-7.

44. Makrygiannakis D, Lundberg K, Ulfgren AK, Klareskog L, Catrina A. Citrullination is an inflammation dependent process. Ann Rheum Dis 2006; 65 Suppl 1: A24.

45. Bongartz T, Cataert T, Atkins SR, Harle P, Myers JL, Turesson $\mathrm{C}$ et al Citrullination in extra-articular manifestations of rheumatoid arthritis. Rheumatology 2007; 46: 70-5.

46. Fery H, Jones M, Vaux DJ, Roberts IS, Cornall RJ. The cellular location of self antigen determines the positive and negative selection of autoreactive B cells. J Exp Md 2003; 198: 1415-25.

47. Erik R Vossenaar, Albert JW Zendman and Walther $\mathrm{J}$ van Venrooij Citrullination, a possible functional link between susceptibility genes and rheumatoid arthritis Arthritis Res Ther 2004; 6:1-5
48. Feldmann M, Brennan FM, Maini RN. Rheumatoid arthritis. Cell 1996; 85: 307-10.

49. Gabriel SE. The epidemiology of rheumatoid arthritis. Rheum Dis Clin North Am 2001; 27: 269-81.

50. Zanelli E, Breedveld FC, de Vries RR. HLA class II association with rheumatoid arthritis: facts and interpretations. Hum Immunol 2000; 61: 1254-61.

51. Dessen A, Lawrence CM, Cupo S, Zaller DM, Wiley DC: X-ray crystal structure of HLA-DR4 (DRA*0101, DRB $1 * 0401)$ complexed with a peptide from human collagen II. Immunity 1997; 7: 473-81.

52. van Gaalen FA, van Aken J, Huizinga TW, Schreuder GM, Breedveld FC, Zanelli E et al. Association between HLA class II genes and autoantibodies to cyclic citrullinated peptides (CCPs) influences the severity of rheumatoid arthritis. Arthritis Rheum 2004; 50: 2113-21.

53. Kroot EJ, de Jong BA, van Leeuwen MA, Swinkels H, van den Hoogen FH, van't Hof M, et al. The prognostic value of anti-cyclic citrullinated peptide antibody in patients with recent-onset rheumatoid arthritis. Arthritis Rheum 2000; 43: 1831-5.

54. De Vries RRp, Huizinga TW, Toes RE. HLA and RA revisited: citrullinated food for the SE hypothesis, the DR6 effect and NIMA. J Immunol 2006; 67: 454-9.

55. Stuehr DJ. Structure-function aspects in the nitric oxide synthases. Annu Rev Pharmacol Toxicol 1997; 37 : 339-59.

56. Bogdan C. nitric oxide and the immune response. Nat Immunol 2001; 2: 907-16.

57. Frucht DM, Fukao T, Bogdan C, Schindler H, O'Shea JJ, Koyasu S Interferon production by antigen presenting cells: mechanisms emerge. Trends Immunol 2001; 22: 556-60.

58. Werner-Felmayer G, Golderer G, Werner ER. Tetrahydrobiopterin biosynthesis, utilization and pharmacological effects. Curr. Drug Metabol 2002; 3: 159-73.

59. Nathan C. Nitric oxide as a secretory product of mammalian cells. FASEB J. 1992; 6: 3051-64.

60. Kolb H, Kolb-Bachofen V. Nitric oxide in autoimmune disease: cytotoxic or regulatory mediator. Immunol Today 1998; 19: 556-61.

61. Bogdan C. Nitric oxide and the immune response. Nat Immunol. 2001; 2: 907-16.

62. Bogdan C. The multiplex function of nitric oxide in (auto)immunity. J Exp Med 1998; 187: 1361-5.

63. Gilkeson, GS, Mudgett JS, Seldin MF, Ruiz P, Alexan$\operatorname{der}$ AA, Misukonis MA et al. Clinical and serologic manifestations of autoimmune disease in MRL-lpr/lpr mice lacking nitric oxide synthase type 2. J Exp Med 1997; 186: 365-373.

64. McCartney-Francis N L, Song XY, Mizel DE, Wahl, S M. Selective inhibition of inducible nitric oxide synthase exacerbates erosive joint disease. J Immunol 2001; 166: 2734-40.

65. Ling S, Lai A, Borschukova O, Pumpens P, Holoshitz J. Activation of nitric oxide signalling by the rheumatoid arthritis shared epitope. Arthritis Rheum 2006; 54 : 3423-32.

66. Hazes JM, Dijkmans BA, Vandenbroucke JP, de Vries RR, Cats A. Lifestyle and the risk of rheumatoid arthri- 
tis: cigarette smoking and alcohol consumption. Ann Rheum Dis 1990; 49: 980-2.

67. Heliovaara M, Aho K, Aromaa A, Knekt P, Reunanen A. Smoking and risk of rheumatoid arthritis. J Rheumatol 1993; 20: 1830-5.

68. Krishnan E, Sokka T, Hannonen P. Smoking-gender interaction and risk for rheumatoid arthritis. Arthritis Res Ther 2003; 5: R158-62.

69. Stolt P, Bengtsson C, Nordmark B, Lindblad S, Lundberg I, Klareskog L et al. Quantification of the influence of cigarette smoking on rheumatoid arthritis: results from a population based case-control study, using incident cases. Ann Rheum Dis 2003; 62: 835-41.

70. Symmons DP, Bankhead CR, Harrison BJ, Brennan P, Barrett EM, Scott DG et al. Blood transfusion, smoking, and obesity as risk factors for the development of rheumatoid arthritis: results from a primary care-based incident case-control study in Norfolk, England. Arthritis Rheum 1997; 40: 1955-61.

71. Uhlig T, Hagen KB, Kvien TK. Current tobacco smoking, formal education, and the risk of rheumatoid arthritis. J Rheumatol 1999; 26: 47-54.

72. Voigt LF, Koepsell TD, Nelson JL, Dugowson CE, Daling JR. Smoking, obesity, alcohol consumption, and the risk of rheumatoid arthritis. Epidemiology 1994; 5: 525-32.

73. Pedersen M, Jacobsen S, Klarlund M, Pedersen BV, Wiik A, Wohlfahrt J et al. Environmental risk factors differ between rheumatoid arthritis with and without au- to-antibodies against cyclic citrullinated peptides. Arthritis Res Ther 2006; 8: R133.

74. Padyukov L, Silva C, Stolt P, Alfredsson L, Klareskog L. A gene-environment interaction between smoking and shared epitope genes in HLA-DR provides a high risk of seropositive rheumatoid arthritis. Arthritis Rheum 2004; 50: 3085-92.

75. Mattey DL, Dawes PT, Clarke S, Fisher J, Brownfield A, Thomson W et al. Relationship among the HLADRB1 shared epitope, smoking, and rheumatoid factor production in rheumatoid arthritis. Arthritis Rheum 2002; 47: 403-7.

76. Klareskog L, Stolt P, Lundberg K, Kallberg H, Bengtsson $\mathrm{C}$, Grunewald $\mathrm{J}$ et al. A new model for an etiology of rheumatoid arthritis: smoking may trigger HLADR (shared epitope) - restricted immune reactions to autoantigens modified by citrullination. Arthritis Rheum 2006; 54: 38-46.

77. Hye-Soon Lee, Irigoyen P, Kern M, Lee A, Batliwalla F, Khalili H, et al. Interaction Between Smoking, the Shared Epitope, and Anti-Cyclic Citrullinated Peptide A Mixed Picture in Three Large North American Rheumatoid Arthritis Cohorts Arthritis Rheum 2007; 56: 1745-53.

78. Michou L, Teixeira VH, Pierlot C, Lasbleiz S, Bardin T, Dieudé $\mathrm{P}$, et al Associations between genetic factors, tobacco smoking and autoantibodies in familial and sporadic rheumatoid arthritis. Ann Rheum Dis 2008; 67: 466-70. 